\title{
Effects of Electrode Types on the Microstructure, Tensile and Hardness Properties of 304 L Austenitic Stainless Steel Heat-Affected Zone (HAZ)
}

\author{
Bolarinwa Johnson Kutelu1, Emmanuel Gbolade Adubi², Saliu Ojo Seidu ${ }^{3}$ \\ ${ }^{1}$ Department of Minerals and Petroleum Resources Engineering, Federal Polytechnic, Ado Ekiti, Nigeria \\ ${ }^{2}$ Department of Mechanical Engineering, Federal Polytechnic, Ado Ekiti, Nigeria \\ ${ }^{3}$ Department of Metallurgical and Materials Engineering, Federal University of Technology, Akure, Nigeria \\ Email: seidu2@yahoo.co.uk
}

How to cite this paper: Kutelu, B.J., Adubi, E.G. and Seidu, S.O. (2018) Effects of Electrode Types on the Microstructure, Tensile and Hardness Properties of $304 \mathrm{~L}$ Austenitic Stainless Steel Heat-Affected Zone (HAZ). Journal of Minerals and Materials Characterization and Engineering, 6 , 531-540.

https://doi.org/10.4236/jmmce.2018.65038

Received: November 30, 2017

Accepted: August 28, 2018

Published: August 31, 2018

Copyright $\odot 2018$ by authors and Scientific Research Publishing Inc. This work is licensed under the Creative Commons Attribution International License (CC BY 4.0).

http://creativecommons.org/licenses/by/4.0/

\begin{abstract}
Submerged arc welding (SAW) has been well utilised for the production of weld joints in $304 \mathrm{~L}$ ASS for various industrial application. However, effective performance of the material in service has been hampered by improper choice of electrode. Therefore, in this study, effects of different types of electrode on the microstructure and tensile property of type $304 \mathrm{~L}$ austenitic stainless steel heat-affected zone (HAZ) were studied. Chemical composition of the as-received sample was determined. A number of samples were cut from the as-received sample. Afterwards, two half were joined together with $308 \mathrm{~L}, 312 \mathrm{~L}$ and 316 electrodes at a controlled welding speed, current and voltage of $4.6 \mathrm{~mm} / \mathrm{s}, 160 \mathrm{~A}$ and $30 \mathrm{~V}$ to produce a constant heat input of $626.09 \mathrm{~J} / \mathrm{mm}$. An automatic SAW machine with Model Type: DX3-301, and Frequency: $50 \mathrm{~Hz}$ was used. And based on ASTM standard, tensile and hardness samples were prepared from the as-received and HAZs. Tensile and hardness measurements were made. Also, specimens for microscopy studies were prepared from the HAZ and as-received samples. From the results, microstructures of the HAZs revealed varied volume fraction of austenite and ferrite phases and grain sizes, and at austenite and ferrite grain boundaries, chromium carbide formation and precipitation were observed. The weld joint produced with $308 \mathrm{~L}$ electrode revealed optimum UTS value and YS value of 475 and 325 respectively. While weld joint produced with $316 \mathrm{~L}$ electrode has superior ductility of value $41 \%$. Irrespective of the types of electrode used, the as-received sample revealed superior tensile properties over the weld joints. Also, optimum hardness value of 45.7 HRA was obtained with 308 L. Hardness value of the as-received sample was higher than that of HAZ samples.
\end{abstract}




\section{Keywords}

Heat-Affected Zone, Stainless Steel, Volume Fraction, Microstructures, Hardness, Tensile

\section{Introduction}

The Type 304 L Austenitic Stainless Steel (ASS) has featured prominently in different areas of engineering applications, including metallurgical, mechanical, chemical, automobile and nuclear industries. One major factor for its wide acceptance in these areas is its good welding characteristics [1]. Although, different arc welding techniques, which include shielded metal arc welding (SMAW), gas tungsten arc welding (GTAW), submerged arc welding (SAW), and plasma arc welding (PAW) have been used to join the type 304 L ASS [2] [3] and [4]. And due to ease of process control, high deposition rate, time savings, reduced cost, excellent surface appearance, invisible arc, lower welder skill requirement, improved repair procedure and increased efficiency and productivity, the SAW process has been widely utilized relative to the other techniques in these various areas of applications for the production of weld joints [5] [6].

The weld joint is comprised of base metal (BM), heat-affected zone (HAZ) and fusion zone (FZ), and in service, performance of the weld joint is determined by the microstructural characteristics of these zones. However, due to differently feature microstructures in the HAZ, resulting from thermal cycles, which correspond to different mechanical properties, the HAZ becomes more critical than BM and FZ. Microstructural characteristics of the weld joint can be influenced by electrode composition [7] [8]. In SAW, weld joints are produced by chemical and physical reaction of the weld electrode, the base metal and the flux and the alloying elements coming from them [9]. The chemical compositions of the weld electrode can influence strength and toughness of weld metal; during the solidification of weld joint, volume fraction of acicular ferrite and $\delta$-ferrite have been influenced by electrode composition [10].

Selection of electrode in maintenance of welding is a very important step for achieving the desired results. The two major factors, which basically control the selection of electrodes, are: 1) Types of base material. 2) Service condition. Though there are other factors, which can influence the choice on welding electrodes, the above two factors primarily decide the welding electrodes. The different types of base materials that are normally encountered in any industry are (a) carbon and low alloy steels, (b) stainless steels, (c) austenitic Mn steels and (d) cast iron. A number of investigations on the microstructural and mechanical behavior of SAW welded $304 \mathrm{~L}$ ASS have appeared in learned journal; however the desired attention required by the HAZ has not been adequately addressed. Hence, in this study, 312 L ASS, 308 L ASS and 316 L ASS electrodes were used to produce $304 \mathrm{~L}$ butt joint SAW welded samples, with particular emphasis on 
HAZ; this is with a view to determining the best match for optimum service performance.

\section{Materials and Methods}

\subsection{Materials}

The materials employed for the work included type $304 \mathrm{~L}$ austenitic stainless steel plate sheet of $8 \mathrm{~mm}$ thickness and welding electrodes with the following specifications: AWS $308 \mathrm{~L}$, AWS E312L and AWS E316 and diameter $\phi=2.5$ $\mathrm{mm}$.

\subsection{Method}

\subsubsection{Spectrometric Analysis of the As-Received Sample}

Chemical analysis of the as-received $304 \mathrm{~L}$ austenitic stainless steel plate was done by optical emission spectrometry using AR 430 metal analyzer and the result is depicted in Table 1. While the composition of the different electrode used such as $308 \mathrm{~L}, 312 \mathrm{~L}$ and $316 \mathrm{~L}$ are shown in Tables $2-4$ respectively.

\subsubsection{Weld Preparation and Design}

Samples with length $50 \mathrm{~mm}$, breadth $3.5 \mathrm{~mm}$ and thickness $4.5 \mathrm{~mm}$ were cut from the plate with hacksaw; the use of hacksaw was informed by the need for avoidance of distortion and thermal damage from thermal cutting [11]. To allow for sufficient root penetration single bevel-butt joint design configuration with $60^{\circ}$ within the edges and root opening (air gaps) of $2.5 \mathrm{~mm}$ was adopted Care was taken not to allow the root opening to exceed twice the specified gap [12] [13]. Before welding all the edges were thoroughly cleaned in order to avoid any source of contamination like rust, scale, dust, oil, moisture that could creep into the weld metal and later on could result possibly into a weld defect [14] and depicted in Figure 1 is the experimental sample with single $\mathrm{V}$ geometry.

\subsubsection{Gas Tungsten Arc Welding Process}

An automatic SAW machine with Model Type: DX3-301, and Frequency: $50 \mathrm{~Hz}$ SAW was used for the welding. Prior welding, edges and area adjoining the samples were cleaned of dust using wire brush. Afterwards, the samples were then positioned with respect to each other, aligned accurately, tacked sparingly and welded using $308 \mathrm{~L}, 312 \mathrm{~L}$ and $316 \mathrm{~L}$, electrodes selection was based on American Society of Mechanical Engineers (ASME) standard, and it was metal

Table 1. Chemical composition of the as-received $304 \mathrm{~L}$ austenitic stainless steel plate.

\begin{tabular}{cccccccccc}
\hline Element & $\mathrm{C}$ & $\mathrm{Si}$ & $\mathrm{S}$ & $\mathrm{P}$ & $\mathrm{Mn}$ & $\mathrm{Ni}$ & $\mathrm{Cr}$ & $\mathrm{Mo}$ & $\mathrm{V}$ \\
\% Wt & 0.0367 & 0.6489 & 0.0513 & 0.0505 & 1.8798 & 8.0798 & 18.4032 & 0.3194 & 0.0750 \\
\hline Element & $\mathrm{Cu}$ & $\mathrm{Nb}$ & $\mathrm{Co}$ & $\mathrm{Al}$ & $\mathrm{Pb}$ & $\mathrm{Ca}$ & $\mathrm{Zn}$ & $\mathrm{Fe}$ & \\
$\% \mathrm{Wt}$ & 0.8713 & 0.1036 & 0.1718 & 0.0265 & 0.0126 & 0.0046 & 0.0313 & 69.6502 \\
\hline
\end{tabular}


Table 2. Chemical composition of 308 L electrode.

\begin{tabular}{ccccccccc}
\hline Element & $\mathrm{Ti}$ & $\mathrm{Si}$ & $\mathrm{S}$ & $\mathrm{P}$ & $\mathrm{Mn}$ & $\mathrm{Ni}$ & $\mathrm{Cr}$ & $\mathrm{Mo}$ \\
\hline$\% \mathrm{Wt}$ & 0.030 & 0.6489 & 0.0513 & 0.0405 & 1.8599 & 10.20 & 18.4032 & 0.3194 \\
\hline
\end{tabular}

Table 3. Chemical composition of $312 \mathrm{~L}$ electrode.

\begin{tabular}{ccccccccc}
\hline Element & $\mathrm{C}$ & $\mathrm{Si}$ & $\mathrm{S}$ & $\mathrm{P}$ & $\mathrm{Mn}$ & $\mathrm{Ni}$ & $\mathrm{Cr}$ & $\mathrm{Mo}$ \\
\hline$\% \mathrm{Wt}$ & 0.030 & 0.40 & 0.010 & 0.018 & 1.8599 & 10.20 & 19.58 & 0.319 \\
\hline
\end{tabular}

Table 4. Chemical composition of $316 \mathrm{~L}$ electrode.

\begin{tabular}{cccccccccc}
\hline Element & $\mathrm{C}$ & $\mathrm{Si}$ & $\mathrm{S}$ & $\mathrm{P}$ & $\mathrm{Mn}$ & $\mathrm{Ni}$ & $\mathrm{Cr}$ & $\mathrm{Mo}$ & $\mathrm{Ti}$ \\
\hline$\% \mathrm{Wt}$ & 0.03 & 0.349 & 0.015 & 0.018 & 0.929 & 9.07 & 18.4032 & 0.282 & 0.006 \\
\hline
\end{tabular}

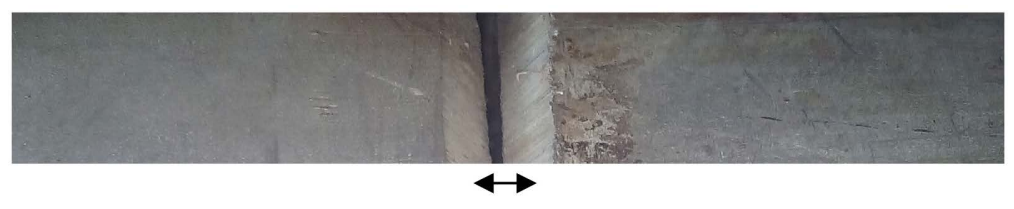

$2.5 \mathrm{~mm}$

Figure 1. Experimental sample with single V configuration.

manually fed to the work piece during welding. The weldments were produced with single-pass under $99.97 \%$ argon gas shielding at a flow rate of 15 litre per minute.

\subsubsection{Tensile Samples Preparation and Testing}

The preparation of the HAZs tensile samples were done in accordance with ASTM E 8-04. Wire-cut electric discharge machining was used to remove flashing and other surface irregularities from the top and bottom surfaces of the tensile specimens. Cross-sectional area and pre-determined gauge length of the samples were measured, and to ensure that the samples undergo deformation, they were placed in the proper grippers. The test was carried out in $\mathrm{x}$-direction with INSTRON tensile testing machine; load was applied at the rate of 0.5 $\mathrm{mm} / \mathrm{min}$.

\section{Samples Preparation for Hardness Testing}

Figure 2 is a sample of the SAW weldment. Prior to testing, sides and ends of the samples (base metal and weldment) were properly ground, this is necessary to ensure dimensional accuracy; their surfaces were also ground, to maintain flatness and stability. Hand grinder was used for the grinding. Thereafter, the samples were mounted in bakelite, polished and etched by Vilella's reagent. Preparation of the samples was in accordance with ASTM E 8-04 standard. Micro-hardness test was carried out on all the weldment samples using Vickers micro hardness tester LECO 700AT with diamond pyramid. Tests were performed on the transverse cross-section of the base metal (BM), heat affected zone 


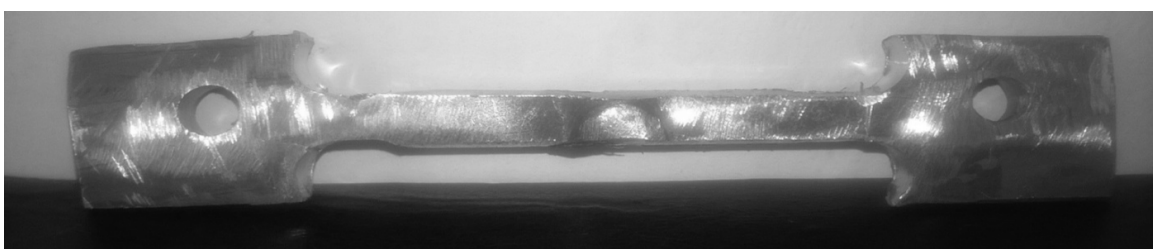

Figure 2. A sample of the SAW weldment.

(HAZ), weld metal (WM). On each of the three zones of the test samples, three indentations were made with gap of about $3 \mathrm{~mm}$ in-between. The indentations were made using a $980 \mu \mathrm{N}$ load and a dwell time of $10 \mathrm{~s}$. The specimens were placed with the surface on the anvil, and slowly turning the hand wheel until they were raised to touch the indenter. The numbers were read directly from the dial indicator and converted to the Vicker number. The test was carried out in air at room temperature based on ASTM E384 standard.

\subsubsection{Hardness Sample Preparation and Measurement}

Surfaces of the (as-received and HAZ) samples with dimensions $20 \mathrm{~mm}$ length, $20 \mathrm{~mm}$ breadth and $8 \mathrm{~mm}$ thickness (Figure 3) were properly ground to give it flat and stable surface using a hand grinder. Thereafter, hardness measurement was made using Digital Rockwell hardness $\left(\mathrm{H}_{\mathrm{RA}}\right)$ Tester with 16 inches indenter and $60 \mathrm{gf}$ indenting load with a dwell time of $10 \mathrm{~s}$. Hardness measurements were made in three different locations, and the average value was taken [11].

\subsubsection{Metallography}

Samples for metallographic examination were prepared from the weldments. In order to make the sample convenient for handling, transverse sections were prepared by mounting on thermosetting material known as Bakelite, their surfaces flattened by filing and grinding using laboratory grinding and polishing machines, a set of emery papers of 100, 240,320,600, 8001000 and 1200 p were used. Grinding was done in order of coarseness of the papers, and as each specimen was change from one emery papers to the other, it was turned through an angle of $90^{\circ}$ so as to remove the scratches sustained from the previous grinding. After grinding, the specimens were polished using rotary polishing machine, a polishing cloth was also introduced to give it mirror like surface [8] [11]. Thereafter, the specimens were then etched in a solution of $1 \mathrm{ml} \mathrm{HCL}+3 \mathrm{ml} \mathrm{\textrm {HNO } _ { 3 }}$ $+1 \mathrm{ml}$ glycerol and the microstructures examined at a magnification of $400 \times \times$ using metallurgical microscope.

\section{Results and Discussion}

Figures 4(a)-(c) are HAZs microstructures of SAW weld joints produced with $302 \mathrm{~L}, 316 \mathrm{~L}$ and $308 \mathrm{~L}$ respectively. The HAZs microstructures are comprised majorly of austenite matrix with varied volume fraction of ferrite grains, sensitized regions in form of white patches and precipitates in form of dark tiny particles in varied amounts are dispersed within the austenite matrix. The varied 


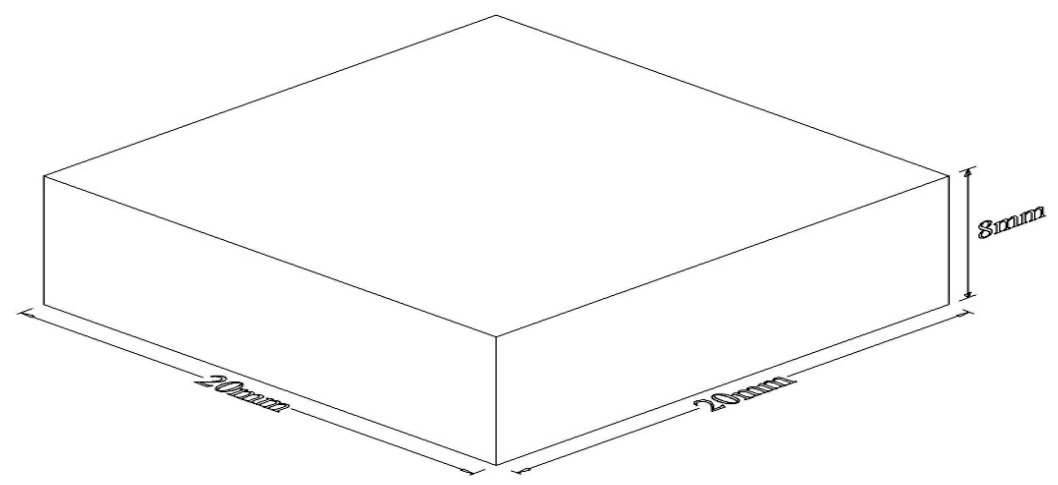

Figure 3. Hardness test specimen used for the experimental work.
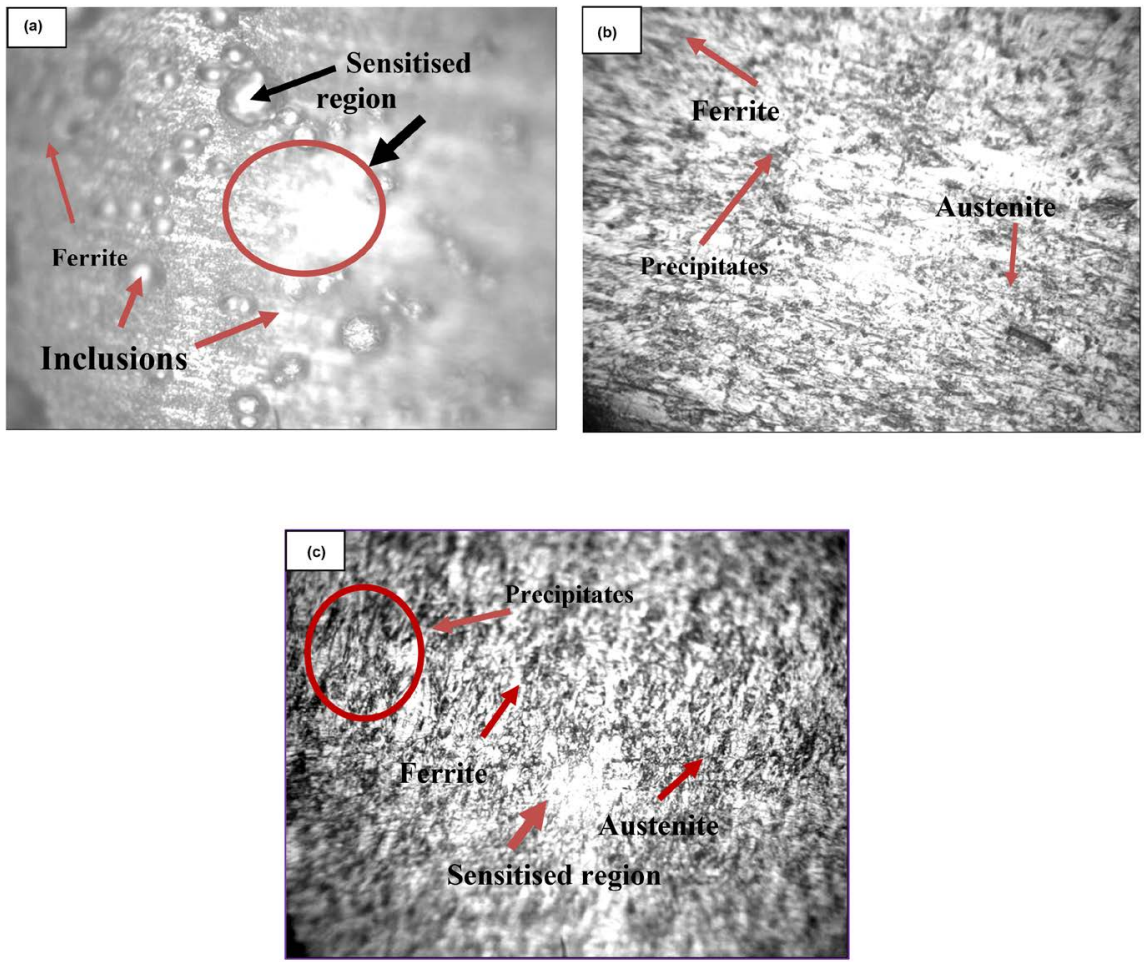

Figure 4. (a)-(c) Optical micrographs of SAW weld joints produced with 312, 316 and 308 electrodes, after etching in solution of $1 \mathrm{ml} \mathrm{HCl}+3 \mathrm{ml} \mathrm{HNO}_{3}+1 \mathrm{ml}$ glycerol at mag. $\times 400$.

volume fraction of ferrite observed may be due to difference in cooling rates that resulted from heat inputs of the electrodes [15]. It is well known that, electrode heat input varies, and can be classified into high and low heat inputs [5]. The observed sensitised regions may be chromium carbide precipitates. The precipitates, which may have been formed at high temperature, may be due to the welding heat. Also, the inclusions may have resulted from reaction of oxidation with some elements at the high temperature of welding to form intermetallic compounds, which may include oxide of chromium and nickel, and the precipitates may be accounted for by the present of impurities in the weld metal and contaminants within the welding atmosphere. 
In SAW, the use of low heat electrode remains one effective approach for reducing welding heat input, and hence improving HAZs mechanical properties [5]. For ASS, as the welding heat input decreases, more volume fraction of ferrite is produced, and since ferrite grains are stronger than austenite grains, with more ferrite phase, the mechanical properties of HAZs are improved. Also, with low heat input, the austenite grain size decreases, leading to improvement in HAZ mechanical properties [6]. Hence, the improved tensile properties (UTS and YS) of weld joints produced with $308 \mathrm{~L}$, whose values are $475 \mathrm{MPa}$ and 325 MPa respectively, as seen in stress strain curve in Figure 5 may be attributed to low heat input of the electrode relative to the $312 \mathrm{~L}$ and $316 \mathrm{~L}$ electrodes. Past research findings have shown that the use of low heat input electrodes increases the amount of weld metal deposition, weld penetration depth increases and sharpens weld metal tip shape [15]. Hence, enhancing the mechanical properties, and thus the service performance of the weld joints. The same justification for strength may be applicable for the observed relative superior hardness property of the weld joint produced by $308 \mathrm{~L}$ with value of as seen in Figure 6. As heat input decreases, smaller grains are produced, which allows for greater interactions between dislocations, the grain size and the available room for their gliding through the lattice is reduced.

Nearness in mechanical properties of the base plate and HAZ is dependent on similarity in their chemical compositions. Hence, for the production of high quality weld joints, chemical composition of the electrode becomes a critical parameter. And this may be contributory to the observed variation in tensile and hardness properties of the HAZs. From the chemical compositions presented in Tables 1-4, it can be seen that unlike electrodes $312 \mathrm{~L}$ and $316 \mathrm{~L}$, most alloying elements for the base metal (Table 1) are replicated for $308 \mathrm{~L}$ electrode thereby making it more compatible for this application than the other ones. For instance

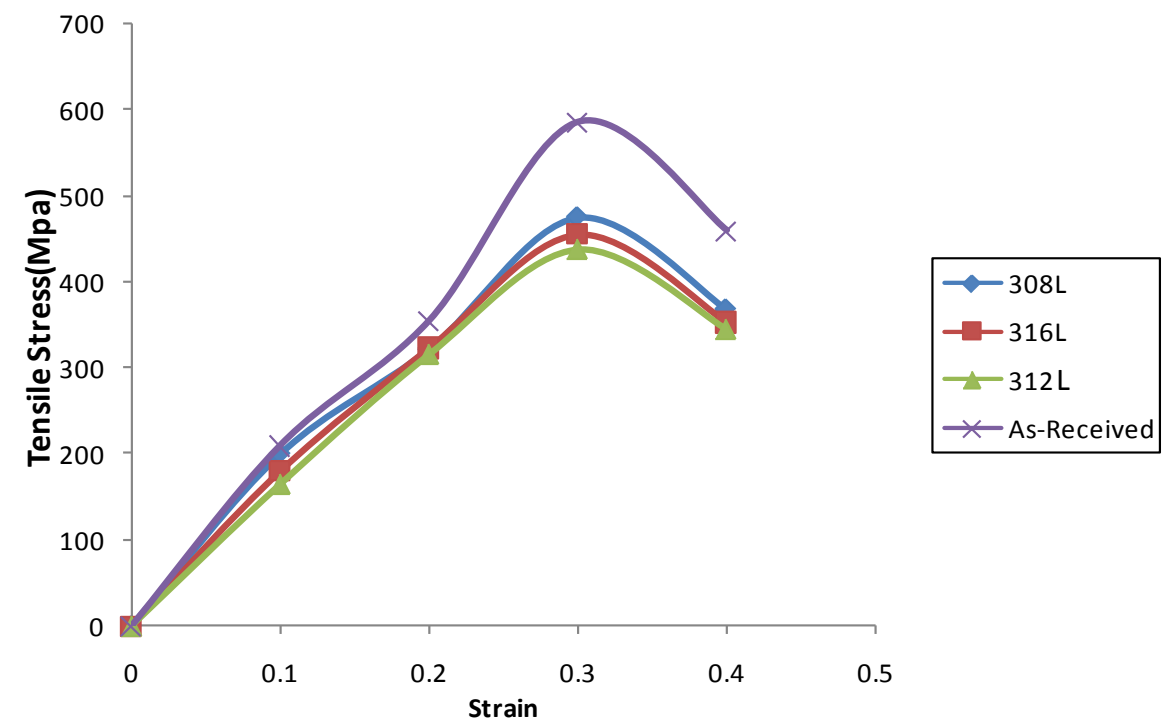

Figure 5. Tensile stress-strain curves of the HAZ samples at a range of electrode types, and as-received sample. 


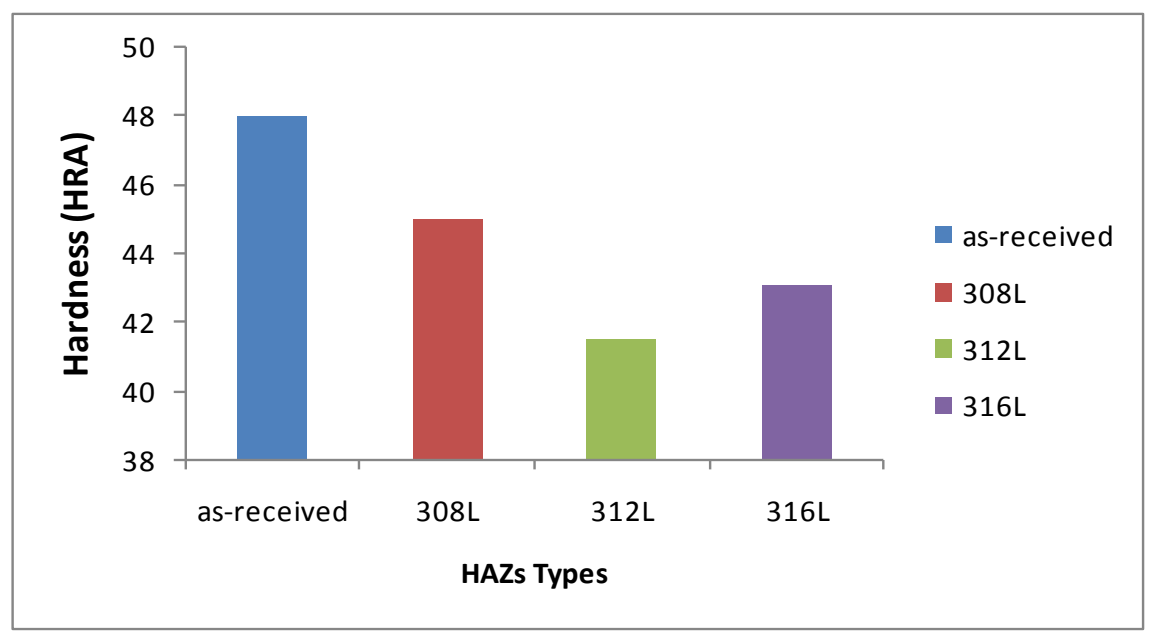

Figure 6. Hardness characteristics of as-received sample and HAZs produced with $308 \mathrm{~L}$, $312 \mathrm{~L}$ and $316 \mathrm{~L}$ electrodes.

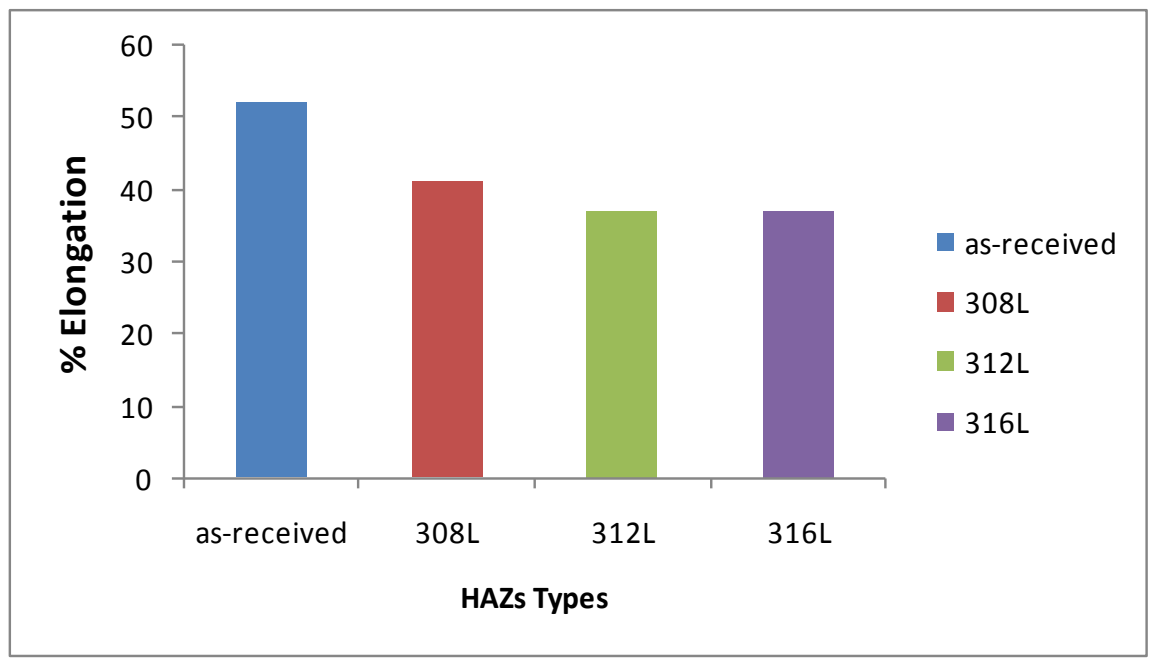

Figure 7. Elongation behaviour of as-received and the HAZs produced with $308 \mathrm{~L}, 312 \mathrm{~L}$ and $316 \mathrm{~L}$ electrodes.

effects of $\mathrm{Cr}$ and $\mathrm{Mo}$, (as alloying elements in BM and $308 \mathrm{~L}$ electrode) on the final HAZ microstructure after solidification promotes hardness by formation of acicular ferrite and fine carbides in the weld [10] [16]. The presence of Ti $316 \mathrm{~L}$ may have accounted for reduction in ultimate tensile strengths and elongation percentages of the HAZ [17] (Figure 7). Welding low carbon steel with low carbon filler metal and martensitic and semi austenitic precipitation hardening stainless steel with type 630 filler metal have given optimum weld joint performance in different applications; provide the weld joint is devoid of defects including discontinuities, entrained contaminants or porosity [18] [19].

Also, the observed variation in mechanical properties may have been informed by differences in electrode extension. It is well known, that the amount of resistant heating which occurring in the electrode is governed by electrode extension, if the electrode extension is short, heating effect will be small and pe- 
netration will be deep, if on the other hand, the extension is increased, heating effects and penetration rate are increased and deposition reduced [8].

\section{Conclusions}

Based on the results of the findings, the following conclusions were drawn:

1) The microstructures of the $316 \mathrm{~L}, 312 \mathrm{~L}$ and $308 \mathrm{~L}$ HAZs are comprised of austenite matrix with varied volume fraction of ferrite.

2) Inclusions, chromium carbide formation (white patches) and precipitates (dark tiny spots) are seen in the HAZs microstructures.

3) Optimum tensile properties (UTS, YS and \%E) were obtained with $308 \mathrm{~L}$ electrode, and tensile properties of the HAZs samples were found to be relatively lower when compared with the as-received sample.

4) Optimum hardness value was obtained with $308 \mathrm{~L}$ as compared to 316 and 312 electrodes respectively.

Hardness value of the as-received sample was high relative to HAZs produced with $308 \mathrm{~L}, 316 \mathrm{~L}$ and $312 \mathrm{~L}$ respectively.

\section{Conflicts of Interest}

The authors declare no conflicts of interest regarding the publication of this paper.

\section{References}

[1] Fowless, R.J. and Blake, S.E. (2008) Influence of Heat Input on Austenitic Stainless Steel Weld Properties. African Fusion, 1, 17-24.

[2] Lee, W.-S., Tzeng, F.-T. and Lin, C.-F. (2005) Mechanical Properties of 304L Stainless Steel SMAW Joints under Dynamic Impact Loading. Journal of Materials Science, 40, 439-484. https://doi.org/10.1007/s10853-005-1920-0

[3] El-Batahgy, A.M. (1997) Effect of Lazer Welding Parameters on Fusion Zone Shape and Solidification Structure of Austenitic Stainless Steels. Materials Letters, 32, 155-163. https://doi.org/10.1016/S0167-577X(97)00023-2

[4] Ramazan, Y. and Huseyin, U. (2002) Mechanical Properties of Austenitic Stainless Steels Welded by GMAW and GTAW. Journal of Marmara of Pure and Applied Sciences, 18, 97-113.

[5] Kolhe, K.P. and Datta, C.K. (2008) Prediction of Microstructure and Mechanical Properties of Multipass SAW. Journal of Materials Processing Technology, 197, 241-249. https://doi.org/10.1016/j.jmatprotec.2007.06.066

[6] Chandel, R.S., Seow, H.P. and Cheong, F.L. (1997) Effect of Increasing Deposition Rate on the Bead Geometry of Submerged Arc Welds. Journal of Materials Processing Technology, 72, 124-128. https://doi.org/10.1016/S0924-0136(97)00139-8

[7] Iordachescu, M., Ruiz-Hervias, J., Iordachescu, D., Valiente, A. and Caballero, L. (2010) Thermal Influence of Welding Process on Strength Overmatching of Thin Dissimiliar Joints. Welding in the World, 65, 201-209.

[8] Bipin, K.S. and Tewarl, S.P. (2010) A Review on Effect of Arc Welding Parameters on Mechanical Behavior of Ferrous Metals/Alloys. Internal Journal of Engineering 
Science and Technology, 2, 1425-1432.

[9] Peng, Y., Chen, W. and Xu, Z. (2001) Study of High Toughness Ferrite Wire for Submerged Arc Welding of Pipeline Steel. Materials Characterization, 47, 67-73. https://doi.org/10.1016/S1044-5803(01)00155-3

[10] Zhang, Z. and Farrar, R.A. (1997) Influence of Mn and Ni on the Microstructure and Toughness of C-Mn-Ni Weld Metals. Welding Journal, 76, S183-S196.

[11] Olaniran, O., Aribo, S. and Kutelu, B.J. (2010) Effect of Austempering Time on the Mechanical Properties of Austempered Ductile Iron. The Pacific Journal of Science and Technology, 11, 102-106.

[12] Sadeghian, M., Shamanian, M. and Shafyei, A. (2014) Effect of Heat Input Microstructure and Mechanical Properties of Dissimilar Joints between Super Duplex Stainless Steel and High Strength Low Alloy Steel. Materials and Design, 60, 678-684. https://doi.org/10.1016/j.matdes.2014.03.057

[13] Lant, T., Robinson, D., Spafford, B. and Storesund, J. (2001) Review of Weld Repair Procedures for Low Alloy Steels Designed to Minimize the Risk of Future Cracking, International Journal of Pressure Vessels and Piping, 78, 813-818.

https://doi.org/10.1016/S0308-0161(01)00094-1

[14] Apurv, C. and Vijaykumar, J.S. (2014) Influence of Welding Heat Input on Mechanical Properties and Microstructure of Austenitic 202 Grade Stainless Steel Weldments. WSEAS Transactions on Applied and Theoretical Mechanics, 9, 222-228.

[15] Bang, K.-S., Park, C., Jung, H.-C. and Lee, J.-B. (2009) Effects of Flux Composition on the Element Transfer and Mechanical Properties of Weld Metal in Submerged Arc Welding. Journal of Metals and Materials International, 5, 471-477. https://doi.org/10.1007/s12540-009-0471-3

[16] Paniagua-Mercado, A.M., Lopez-Hireta, V.M., Mendez-Sanchez, A.F. and Saucedo-Munoz, M.L. (2007) Effect of Active and Nonactive Fluxes on Mechanical Properties and Microstructure in Sub-Merged-Arc Welds of A-36 Steel Plates. Journal of Materials and Manufacturing Processes, 223, 851-863.

[17] Liao, M.T. and Chen, P.Y. (1997) Effect of Shielding-Gas Compositions on the Microstructure and Mechanical Properties of Stainless Steel Weldments. Materials Chemistry and Physics, 55, 145-151. https://doi.org/10.1016/S0254-0584(98)00134-5

[18] Cunat, P.J. (2007) The Welding Stainless Steels. Materials and Application Series, Volume 3. Euro Ino pp. 2-9, 23, 25-28. An Electronic Manual http://www.worldstainless.org/Files/issf/non-image-files/PDF/Euro_Inox/Brochure Weldability_EN.pdf

[19] Lancaster, J.F. (2003) Metallurgy of Welding. Chapman and Hale, London, 106-116. 